\title{
Tensions between the Fisico-Mor and the University of Coimbra: The Accreditation of Medical Practitioners in Ancien-Regime Portugal
}

\author{
Laurinda Abreu*
}

\begin{abstract}
Summary. Institutional relations between the empirical and the academic medical worlds in early modern Portugal were strained over the accreditation of doctors and surgeons. The circumstances surrounding the development of the medical field are examined here from the accession of King Manuel I in 1495 until 1825, the year when the creation of the medical and surgical schools in Lisbon and Porto marked a new paradigm in the academic training of physicians and surgeons. The analysis draws on a relational database of more than 22,000 people who applied for a licence to practise their professions and/or were awarded public appointments (partidos). It focuses on the University of Coimbra and the chief physician (Fisico-Mor) - two authorities created and controlled by the crown-and their conflict over the accreditation of medical practitioners during this period. The aim here is to broaden the study of the history of medicine in Portugal by pointing out the possible consequences of the attitudes held by the chief physician and the University of Coimbra. Throughout the period in question they both appeared to be motivated more by the desire to protect their own interests than by any scientific purpose.
\end{abstract}

Keywords: medical authorities; 'medical'; professions; early modern Portugal

Research into the documentation of Coimbra University, the only university that trained medical doctors in Portugal in the early modern period, shows that the institution blamed the Faculty of Medicine's inability to progress on pernicious competition from the chief physician (Físico-Mor) and his over-willingness to 'make' doctors, together with the negative influence of New Christians-forced converts from Judaism and their descendants. The university's accusation, however, concealed a complex problem that had arisen early in the sixteenth century, when the crown sought to regulate medical practitioners and draw the boundary between empirical practice and medicine based on academic training. The legal framework established at that time recognised the superiority of academic training, but not its exclusivity. The university's limited ability to train doctors was presented as a reason for accepting popular medicine in certain circumstances, and the crown placed the chief physician in charge of licensing and regulating it. The crown also intervened by founding a proto-school of surgery in Lisbon's Todos os Santos Hospital, the primary hospital in Portugal, in $1504{ }^{1}$

*University of Évora, Departamento de História, Largo dos Colegiais 2, 7000 Évora, Portugal. E-mail: Ifsa@uevora.pt

${ }^{1}$ This point will not be examined further here, although Todos os Santos Hospital was the main training centre for surgeons in Portugal, as discussed in Laurinda Abreu,'Training Health Professionals at the Hospital de Todos os Santos (Lisbon) 1500-1800', in Laurinda Abreu and Sally Sheard, eds, Hospital Life: Theory and
Practice from the Medieval to the Modern (Oxford, Peter Lang, 2013), 119-37. The second most important area for training surgeons was in the north of the country, in the hospital attached to the Porto Misericórdia and in the chief surgeon's well-established network of agents, who validated empirical 
The clash between empirical and academic medical training was common in Europe at the time, but in Portugal it was particularly acerbic because of two royal decisions that severely penalised the university. The first made the chief physician responsible for recognising the degrees of doctors who had trained abroad. The second lengthened the medical curriculum in Portugal, thereby denying the Faculty of Medicine any chance of competing with its European counterparts even for Portuguese students, given the closeness of Spanish universities, particularly Salamanca. The resulting war between two authorities founded by and answerable to the crown was not so much about the respective merits of academic medicine and folk medicine as about control over the accreditation of medical practitioners.

This topic will be examined here, from the reign of King Manuel I (1495-1521), the monarch who turned health and welfare issues into matters of governance in Portugal, to the creation of the medical and surgical schools in Lisbon and Porto in 1825, which introduced a new paradigm into the academic training of physicians and surgeons. The principal aim is to broaden the discussion of the difficulties that beset the organisation of the medical profession in early modern Portugal. To a great extent, this discussion has so far remained tied to the religious question, whereby the backward state of Portuguese medical teaching and practice in the early modern period was due to the dominance of the Jesuits and the Inquisition in the university and in society in general and to Portugal's 'purity of blood' policies, which led many Jewish and New Christian doctors to flee the country. The new analysis here draws on a relational database of more than 22,000 people who applied for a licence to practise their professions-mainly surgeons, apothecaries, physicians trained in foreign universities and other health professionals awarded public appointments (partidos), including doctors trained at Coimbra University. ${ }^{2}$

How did Coimbra try to counter the attraction of foreign universities, especially the Faculty of Medicine in Salamanca, for Portuguese students, who came under the chief physician's jurisdiction when they returned to Portugal? What did it do to protect the doctors it trained? Was it easy to move from one professional category to another, as suggested by the university's accusation that the chief physician was selling medical licences to surgeons? These are some of the questions I will try to answer by taking a comprehensive approach to the institutional relationship between the two authorities that

training. Altogether, 4,173 training locations have been identified for the 8,274 licences awarded between 1515 and 1826 , but nearly 40 per cent $(3,220)$ of these licences were issued by the Surgery School in Todos os Santos Hospital alone. Further details on this subject may be found in Laurinda Abreu, 'A misericórdia do Porto e os seus hospitais como centros de formação de cirurgiões (1639-1825)', in Saúde, Ciência, Património-Atas do III Congresso de História da Santa Casa da Misericórdia do Porto (Porto, Santa Casa da Misericórdia do Porto, 2016), 541-57.

${ }^{2}$ The database (referenced as the Medical Professions database, 1430-1826) utilised for this article, originated in a research project funded by the Fundação para a Ciência e a Tecnologia (FCT) (PTDC/HIS-HIS/ 113416/2009). It is composed of data from five main documentary sources stored in the Arquivo Nacional da Torre do Tombo (ANTT), the Portuguese central archives: Chancelarias Régias; Ementas da Casa Real; Desembargo do Paço; Registo Geral de Mercês and Santo Oficio and it includes all the information recorded on the practitioners in question. The fact that the documentation is bureaucratic in nature means that this information is limited in most cases to their place of origin, parentage and professional career, and this is one of the main weaknesses of the database. Only research in the archives of the local authorities or institutions where the practitioners worked might flesh out the information on each of the individuals in question. A systematic survey of sources kept in the Arquivo Histórico Ultramarino relating specifically to the Portuguese Empire is currently under way, and at least 3,000 new records are being added to the database. 
controlled the training of medical practitioners. ${ }^{3} / \mathrm{fn}>$ Religion is not disregarded, of course. Can specific policies for controlling New Christians and excluding them from medical practice be identified, and can their results be quantified? Or can Katharine Park's theory that Christian doctors' support for the religious purges against Jews in medieval Europe may be seen as an opportunity to eliminate unwelcome competition be applied to early modern Portugal? ${ }^{4} / f n>$ José Pardo-Tomás and Àlvar Martínez-Vidal claim that converted physicians in Spain were perfectly integrated into the medical 'establishment' and that problems only arose when their Jewish origins were discovered. ${ }^{5} / \mathrm{fn}>$ Were matters different in Portugal? How important is the religious factor in the documentation examined here? It should be noted, however, that this contribution does not propose to analyse medical studies in Portugal, on which there is an extensive literature, although the field remains open to new interpretations in the light of recent research. Nor does it attempt to assess the complex subject of New Christians and their role in Portuguese medicine, since such a brief discussion could not do it justice. ${ }^{6} / \mathrm{fn}>$

\section{The Institutional Framework}

During the early modern period, a reformist movement arose throughout Europe, from the Italian city states to the kingdoms of Aragon and Castile and from France to England, to mention just a few examples. ${ }^{7} / \mathrm{fn}>$ In Portugal too, regulation of the health care professions and training began systematically in the early sixteenth century, with a view to bringing the field and its practitioners under central control. ${ }^{8} / \mathrm{fn}>$ This took place in the framework of the crown's thorough reform of poor relief and health care arrangements, in which the king called on the whole of society to participate, not least in financial terms. ${ }^{9} / \mathrm{fn}>$ The motives that lay behind the central authorities' involvement in these areas were not only demographic and social (in 1528, Lisbon was one of the largest cities in Europe with 70,000 inhabitants, but the country as a whole was sparsely populated,

\footnotetext{
${ }^{3}$ This article deals only with those health care practitioners who obtained royal approval to practice, which means that in a sense they were practitioners of official medicine. Folk healers (curandeiros and saludadores) are not included here; they have been studied by Timothy Walker, 'The Role and Practices of the curandeiro and saludador in Early Modern Portuguese Society', História, Ciências, SaúdeManguinhos, 2004, 11 suppl.1, 223-37.

${ }^{4}$ Katharine Park, 'Medicine and Society in Medieval Europe, 500-1500', in Andrew Wear, ed., Medicine in Society. Historical Essays (Cambridge: Cambridge University Press, 1992), 77.

${ }^{5}$ José Pardo-Tomás and Àlvar Martínez-Vidal, 'Victims and Experts: Medical Practitioners and the Spanish Inquisition', in J. Woodward and R. Jütte, eds, Coping with Sickness. Medicine, Law, and Human RightsHistorical Perspectives (Sheffield, European Association for the History of Medicine and Health Publications, 2000), 19.

${ }^{6}$ This topic is being developed as part of the ongoing doctoral research by Luís Gonçalves on medical practice and professional regulation in sixteenth-century Portugal.
}

${ }^{7}$ There is a rich literature on this subject. Titles include: Laurence Brockliss and Colin Jones, The Medical World of Early Modern France (Oxford: Clarendon, 1997); Margaret Pelling and Charles Webster, 'Medical Practitioners', in Charles Webster, ed., Health, Medicine, and Mortality in the Sixteenth Century (Cambridge: Cambridge University Press, 1979), 165-235; Paul Slack, The Impact of Plague in Tudor and Stuart England (London: Clarendon Press, 1985); David Gentilcore, Medical Charlatanism in Early Modern Italy (Oxford: Oxford University Press, 2006); Gianna Pomata, Contracting a Cure: Patients, Healers, and the Law in Early Modern Bologna (Baltimore and London: Johns Hopkins University Press, 1998).

${ }^{8}$ This occurred within the wider context of social regulation, as demonstrated in Laurinda Abreu, The Political and Social Dynamics of Poverty, Poor Relief and Health Care in Early-Modern Portugal (London and New York: Routledge, 2016).

${ }^{9}$ See Eduardo Freire de Oliveira, Elementos para a História do Município de Lisboa (Lisbon: Typographia Universal, 1882), XV, 452-523. 
with a population of about $1,200,000)$. There was also a realisation-and this is true not only of Portugal - that such action was politically beneficial, since poor relief and health care enabled the authorities to reach into people's daily lives, thereby furthering the ongoing centralisation of power. ${ }^{10} / \mathrm{fn}>$

Manuel I expanded on a number of isolated measures adopted by his predecessors, such as reforming the hospitals, by institutionalising support for abandoned children, regulating the distribution of charity to the poor, organising the means to fight epidemics and training health care professionals. ${ }^{11} / \mathrm{fn}>$ The best known of all his measures and the one that had the most far-reaching effects is the creation of royal confraternities, or misericórdias, to take charge of assisting the poor, especially the poor sick and the poor in prison. In contrast to these poor relief policies, the effects of royal action in the area of health care remain little known. There is, however, abundant documentary evidence that the measures adopted by King Manuel I and his son João III (1521-57) shaped the course taken by the field in Portugal until the early nineteenth century.

Ever since the fourteenth century at least, the king's principal physician and surgeon had been responsible for the health care professions throughout the country, taking the titles of Chief Physician and Chief Surgeon (Cirurgião-Mor). ${ }^{12} / \mathrm{fn}>$ They were given this role precisely because of their closeness to the monarch and the prestige they gained by caring for his well-being, in keeping with the paternalistic view of royal appointments. ${ }^{13}$ / $\mathrm{fn}>$ This approach was widespread at the time, and led to the establishment of powerful 'medical houses' close to government. In France and elsewhere, these houses became symbols of modernity and development in the medical, surgical and pharmaceutical fields. In Portugal, however, they never developed into professional bodies, although the chief physician held considerable power, granted to him by the Chief Physician's Statute (Regimento do Físico-Mor) of 27 June 1515, revised in 1521.

The 1515 statute was based on certain procedures that had been in place since before 1338 and had been systematised in 1430, but it also incorporated new ideas on the role of the king's principal physician. ${ }^{14} / \mathrm{fn}>$ In general terms it gave the chief physician two main duties: to examine in person the candidates who wished to practise the 'art of physic' and issue them with licences to do so, and to control the practice of the profession. Exemption from the examination was granted to physicians who had graduated from the Lisbon Studium Generale (prior to its transfer to Coimbra in 1537), thus acknowledging the fact that the country's university was independent of the chief physician. The chief physician also held the power to inspect apothecaries and their shops to control the prices of medicines. The 25 February 1521 version of the statute

\footnotetext{
${ }^{10} \mathrm{~A}$ broader view and a specific bibliography may be found in H. Cook, 'Policing the Health of London: The College of Physicians and the Early Stuart Monarchy', Social History of Medicine, 1989, 2, 133.

${ }^{11}$ This interpretation of royal action owes much to Paul Slack, in particular his 'Dearth and Social Policy in Early Modern England', Social History of Medicine, 1992, 5, 1-17.
}

\footnotetext{
${ }^{12}$ As also happened in France but not in Spain, where these duties were performed by the Tribunal del Protomedicato.

${ }^{13}$ For France, see Alexandre Lunel, La maison médicale du roi XVle-XVIIIe siècles. Le pouvoir royal et les professions de santé (Seyssel: Champ Vallon, 2008).

${ }^{14}$ There had been gaps in the inspection and examination of these professionals, however, as demonstrated by Iria Gonçalves, 'Físicos e Cirurgiões Quatrocentistas: as Cartas de Exame', Do Tempo e da História, 1965, 1, 69-112.
} 
strengthened his authority over apothecaries, who were obliged to sit examinations in the same way as medical candidates. By being placed under the chief physician and not the chief surgeon, apothecaries gained an intermediate social and professional status, albeit one that was fully subordinate to doctors, on whom they depended to dispense 'resolvents, purgatives, opiates or other strong and dangerous medicines', for example. ${ }^{15}$ / $\mathrm{fn}>$ The chief physician also held authority over his medical colleagues, since he could now arbitrate in disputes between patients and doctors about fees or poor professional work ('bad treatment'), regardless of where the doctors had been trained. The chief physician thus held powers similar to those assigned to the College of Physicians of London in 1518, amongst others, the difference being that his powers were personal, not collegiate. ${ }^{16} / \mathrm{fn}>$

The crown seems to have been less concerned about the chief surgeon, who continued to work according to the rules laid down in the letter appointing the royal surgeon, Manuel Gil (?-after 1467), as chief surgeon on 25 October 1448. The Chief Surgeon's Statute only appeared on 12 December 1631, detailing his authority over bloodletters, 'midwives, persons who mend arms and legs, give sweat baths, draw teeth and care for the insane,' as well as the requisites he should demand from those sitting examinations for the various professions. ${ }^{17} / \mathrm{fn}>$ Of the three main authorities under which the field of health care professions was organised - the university, the chief physician and the chief surgeon-the latter was not a major problem for the university since he covered professions that the university considered outside its remit, but the chief physician was a different matter, since his statute made him a direct competitor of the Faculty of Medicine.

\section{The University versus the Chief Physician: The Battle over the Training of Medical Practitioners}

The first signs that the university was not at ease with the chief physician can be seen in the early 1530s, and its criticism became more assertive after it moved from Lisbon to Coimbra. In a context where university studies were still strongly marked by the peregrinatio academica, King João III launched a thorough reform of the institution in an attempt to raise it to levels of excellence and thus keep students in the country. ${ }^{18} / \mathrm{fn}>$

The model for this was the reform currently under way at the University of Salamanca, where there was a significant contingent of Portuguese students and teachers. The medical curriculum was modernised in a number of ways, particularly in the teaching and practice of anatomy and surgery. Several Portuguese lecturers were invited back from

\footnotetext{
${ }^{15}$ This rule was introduced alongside the Apothecaries' Statute of 1497, which required a doctor to be present when medicines were being made up.

${ }^{16}$ On the power of the London College of Physicians, see Margaret Pelling, Medical Conflicts in Early Modern London: Patronage, Physicians and Irregular Practitioners, 1550-1640 (Oxford: Oxford University Press, 2003), 1.

${ }^{17}$ On the Chiefs Surgeon's authority, see José Justino de Andrade e Silva, Collecção Chronologica da Legislação Portugueza, 1627-1633 (Lisbon: Imprensa de F. X. de Souza, 1855), 157. On the requirements for those sitting exams, see José Roberto Monteiro
}

de Campos Coelho e Soisa, Systema, ou Collecção dos Regimentos Reais: contém os Regimentos pertencentes à Administração da Fazenda Real (Lisbon: Officina de Francisco Borges de Soisa, 1783), 345-6.

${ }^{18} \mathrm{On}$ the peregrinatio academica, see Mário Farelo, 'On Portuguese Medical Students and Masters Travelling Abroad: An Overview from the Early Modern Period to the Enlightenment', in Andrew Cunningham, Ole Peter Grell and Jon Arrizabalaga, eds, Centers of Medical Excellence?: Medical Travel and Education in Europe, 1500-1789 (Farnham, England; Burlington, VT: Ashgate, 2010), 127-47. 
abroad, together with some foreigners such as the Spaniard Alfonso Rodríguez de Guevara (c. 1520-87), who had been associated with the introduction of anatomical studies in Spain and who arrived in Coimbra in $1556 .{ }^{19} / \mathrm{fn}>$ The royal act of 1546 gave the Portuguese university an advantage over Salamanca by allowing the corpses of criminals and poor people who had died in hospital to be made available for anatomical training and research (preferably corpses of 'foreign persons, such that no scandal may ensue'), as Vesalius had advocated in his recent treatise De humani corporis fabrica (1543). ${ }^{20} / \mathrm{fn}>$ These provisions were enshrined in the university statutes of $1559 .{ }^{21} / \mathrm{fn}>$

As part of these far-reaching reforms, by an act of 4 November 1545 João III increased the length of the medical curriculum in Coimbra to eight years (six years of theoretical studies, followed by two years of practical training under a doctor who practised in the city). ${ }^{22} / \mathrm{fn}>$ The measure caused outrage at the university, which quite reasonably feared that potential students would go in search of shorter courses abroad, particularly in Salamanca, where medical studies took just four years (preceded, as in Coimbra, by a licentiate degree in Arts). ${ }^{23} / \mathrm{fn}>$ Students who graduated abroad would subsequently be accredited by the chief physician. Coimbra complained that this would result in a potentially dangerous situation, adding to the criticism that had been lodged at the Cortes held in Évora in 1535, where the people's representatives had accused the chief physician of exceeding his mandate by granting licences 'to treat with medicine' purely for financial gain, charging one silver mark for every licence issued. ${ }^{24} / \mathrm{fn}>\mathrm{In}$ the belief that his action was endangering people's health, they petitioned the king to allow only physicians and surgeons who held a university degree to be licensed, but João III refused. ${ }^{25 / f n>}$ However, the king went some way towards giving in to the university's demands in the charter of 20 March 1546, which allowed bachelors of medicine trained in Coimbra to 'freely treat' without needing a licence from the chief physician, thus abolishing the need for the two years of practical experience after they had completed their six years of

${ }^{19}$ Between 1537 and 1554, around 30 Portuguese and Spanish lecturers were hired from Salamanca alone. Ángel Marcos de Dios, 'A Universidade de Salamanca e Portugal no Período Barroco', in Marta Teixeira Anacleto, Sara Augusto and Zulmira C. Santos, eds, D. Francisco Manuel de Melo e o Barroco peninsular (Coimbra: Imprensa da Universidade de Coimbra, 2010), 79-94. After arriving in Coimbra, Rodríguez de Guevara published Defeza de Galeno das impugnações de André Vesalio (1559). Theophilo Braga, Historia da Universidade de Coimbra nas suas relações com a instrucção publica portugueza, 4 vols (Lisbon: Typographia da Academia Real das Sciencias, 18921902), II (1555-1700), 769.

${ }^{20}$ Mário Brandão, Documentos de D. João III (Coimbra: Universidade de Coimbra, 1939), III, 71-2.

${ }^{21}$ Estatutos da Universidade de Coimbra de 1559 (Coimbra: University of Coimbra, 1963), 314. On the situation in Salamanca, see Bjørn Okholm Skaarup,
Anatomy and Anatomists in Early Modern Spain (Farnham: Ashgate, 2015).

${ }^{22}$ Braga, Historia da Universidade, II, 791-8.

${ }^{23}$ Essential reading on this issue is Noemí Cubas Martín, 'Salamanca y Coímbra: Universidades peninsulares del Renacimiento. Análisis de la población universitaria através de los grados académicos' (unpublished PhD thesis, Salamanca University, 2014).

${ }^{24}$ The Cortes were an assembly of the estates of the realm at which representatives of the clergy, nobility and common people were able to address the monarch. On charges and possible financial gain, see Capitolos de cortes. E leys que se sobre alguu[n]s delles fezeram (Lisbon, Germã Galharde, 1539), 34v.

${ }^{25} \mathrm{~A}$ somewhat similar argument that charging for medical services endangered people's health was used by doctors in England during the first half of the fifteenth century: see C. Rawcliffe, 'Medicine and Medical Practice in Later Medieval London', Guildhall Studies in London History, 1981, 5, 13-25. 
theoretical studies. The chief physician immediately protested since it meant that they would not have completed their licentiateship and should therefore come under his jurisdiction. ${ }^{26 / f n>~}$

While in practical terms the king was authorising a new class of medical professionals (bachelors) to practise, alongside university licentiates and doctors 'made' by the chief physician, it is not clear what benefit students might gain from completing the full eight years of training, except for the possibility of starting a university career, which required a licentiateship and a doctorate. However, while the king succeeded in raising the status of Coimbra bachelors, he did not resolve the basic problem of the considerably longer medical curriculum in Coimbra compared to Salamanca. To strengthen Coimbra's position, the statutes of 1559 (and all subsequent statutes until 1772) stated that bachelor's degrees in medicine (and also theology) from foreign universities would not be accepted as such in Coimbra. Only licentiateships and doctorates would be granted equivalence, but merely at bachelor's level, and students would have to study for two more years to complete their licentiateship. In other words, the market remained open for the chief physician.

Amid all this confusion a struggle of significant proportions developed between the university and the chief physician. In 1549, the university's rector, Friar Diogo de Murça (before 1513-61), suggested to the king that the 'chief physician's pernicious intervention in the study of medicine' should be stopped in exchange for financial compensation. João III rejected the proposal, which may have encouraged Leonardo Nunes (chief physician, 1554-69) to petition King Sebastião (1557-78) in 1562 to suspend the university statutes, since they undermined his authority by allowing bachelors to practise without having to pass any further examinations.

The king found it difficult to handle the quarrel between the chief physician and the university over their clearly overlapping jurisdictions. On one hand, the chief physician censured the university for not respecting his authority and arresting physicians he had examined and licensed. On the other, the university criticised the chief physician for being more interested in lining his own pockets than in people's health and for feeding a dangerous parallel market that competed with physicians trained by the university. Unsure of how he should react, on 7 July 1561 Sebastião had even ordered a national survey to be conducted to ascertain the state of health care practice in the country. Eventually he rejected the chief physician's petition, just as his predecessor had rejected the university's. ${ }^{27} / \mathrm{fn}>$

The results of the 1561 enquiry are unknown, if indeed it was actually held; nor is there any information on the effects of the 1559 decree by Philip II of Spain banning Spanish teachers from teaching abroad and ordering students to return to Castile. ${ }^{28} / \mathrm{fn}>$ This decree may explain why Alfonso Rodríguez de Guevara spent such a short time at the University of Coimbra, which he left in 1561 to begin a career in Lisbon as doctor to

\footnotetext{
${ }^{26}$ Duarte Nunes do Lião, Leis Extravagantes e Repertório das Ordenações. Nota de Apresentação de Mário Júlio de Almeida Costa (Lisbon: Fundação Calouste Gulbenkian, 1987), 166v et seq.

${ }^{27}$ On the rejection of the chief physician's petition, see Braga, Historia da Universidade, II, 791.

${ }^{28}$ Except for students in Bologna and Naples.
} 
the king and a physician at Todos os Santos Hospital, thereby avoiding having to comply with Philip II's order.

What the documents do show is the crown's investment in the Faculty of Medicine in the late 1560s as part of a project to increase the number of academically trained health care professionals working in the country. In September 1568, 30 annual scholarships were set up for medical students and 20 for apothecary students, to be paid for by 74 municipal councils. In 1575 the king acknowledged these councils' efforts by requiring the university to award the scholarships preferentially to students from the contributing areas. In 1604, during the Iberian Union, King Filipe II codified these measures in the Regimento dos médicos e boticários ('Statute of doctors and apothecaries'), which repeated the content of King Sebastião's 1568 act (or so it claimed, since the original act had 'not been found'), in particular setting the value of medical students' and trainee apothecaries' scholarships at 20,000 réis and 16,000 réis, respectively, and laying down the restriction that they could only be awarded to Old Christians. ${ }^{29} / \mathrm{fn}>$ Two years later, the king more than doubled the councils' contributions, which were to be deposited in what came to be known as the Doctors' and Apothecaries' Chest (Arca dos Médicos e dos Boticários).

With a stroke of the pen the university had been given the opportunity to increase its student numbers and its sources of funding - not just its fee revenue but also the income deriving from its implementation and administration of the whole scheme, from collecting the municipal councils' contributions to selecting scholarship candidates and managing the funds. The 1568 decision almost coincided with the appointment of a new chief physician: Sebastião Rodrigues de Azevedo (before 1556-after 1580) had graduated from Coimbra in 1541 with a doctorate in medicine. ${ }^{30} / \mathrm{fn}>$ As chief physician he came to an agreement with Coimbra University that he would stop issuing licences to physicians trained abroad in exchange for compensation to the value of 200 cruzados (80,000 réis) a year, equivalent to the salaries of several teachers in the Faculty of Medicine. The agreement was given the royal blessing and was later ratified by Dom Nuno de Noronha, the Bishop of Guarda and rector of the university from 1578 to 1586. This information comes from the next chief physician, Fernão Rodrigues Cardoso (15851608), a former lecturer at the University of Coimbra, who in about 1589 reported back to the king on his negotiations with the university to change his statute as chief physician so as to make the agreement drawn up with his predecessor permanent. ${ }^{31} / \mathrm{fn}>$ The fact

\footnotetext{
${ }^{29}$ Between 1580 and 1640 the crowns of Portugal and Spain were united in what is known as the dual monarchy. Three Habsburg kings named Philip (Filipe in Portuguese, Felipe in Spanish) ruled over both countries in that period. As kings of Portugal they were crowned as Filipe I (1580-1598), Filipe II (15981621) and Filipe III (1621-1640). In Spain (where there had already been a King Philip I of Castile, in 1506) they were Philip II, Philip III and Philip IV, respectively. In this article, the name 'Filipe' refers to the king as ruler of Portugal and hence is followed by the Portuguese ordinal. The name 'Philip' (with the
}

corresponding Spanish ordinal) is used only in a purely Spanish context.

${ }^{30}$ The birth and death dates of Rodrigues de Azevedo are unknown; the dates given here are for the first and last reference to him in the documentation.

${ }^{31}$ For information on these chief physicians, see Francis Dutra, 'The Practice of Medicine in Early Modern Portugal. The Role and Social Status of the Físico-mor and the Surgião-mor', in Carleton Sprague Smith and Israel J. Katz, eds, Libraries, History, Diplomacy and the Performing Arts. Essays in Honor of Carleton Sprague Smith (New York: Pendragon Press, 1991), 135-69. 
that he then called for the payment of 400 cruzados suggests that he was complying with the earlier agreement.

Probably on the assumption that the king would ratify the agreement, the new university statutes of 1591 stated that the chief physician would not be allowed to issue licences to practise medicine ('and I order said chief physician to comply and not issue or grant licences to treat to other persons'). ${ }^{32} / \mathrm{fn}>$ However, in 1596 the king in Madrid rejected the agreement reached by the two parties. ${ }^{33} / \mathrm{fn}>$ Even so, in its reform of the following year the university decided to maintain the wording of the 1591 statutes, to the fury of the chief physician, who then threw himself into a frenzy of licensing doctors from abroad, according to the university. In September 1599 the Board of Conscience and Orders (Mesa da Consciência e Ordens) delivered its opinion on the matter, in which it essentially insisted on the arrangement of which the king had disapproved. It supported the university's claim that the chief physician should stop 'examining and giving licences to any graduate' and confine his activity to licensing the 'untaught (idiotas $s^{34} / \mathrm{fn}>$ ), both men and women, to treat with medicine', who were the only ones that should come under his jurisdiction if they practised without a licence. But the Board also agreed with the chief physician that he should be compensated by the university 'since he the supplicant lost in a single year more than two hundred cruzados in examination fees from physicians who graduated from foreign universities. ${ }^{35} / \mathrm{fn}>$

The king must have remained intransigent, because on 12 September 1606 the Board of Conscience and Orders recommended reverting to the previous situation, in which the chief physician would retain his authority to 'give licences to treat to physicians who graduated at other universities'. ${ }^{36} / \mathrm{fn}>$ It added, however, almost certainly at the university's request, that 'he shall examine these as he does the unlearned. And thus they shall be excluded from places where there are Coimbra graduates'. ${ }^{37} / \mathrm{fn}>$ It basically established a difference between degrees obtained abroad and those awarded by Coimbra in cases where there was competition for the same place. In the charter of 12 May 1608, the king consented to the solution proposed by the Board of Conscience and Orders.

At this time the university was in the process of being restructured (under the royal act of 31 December 1603). The Reformações (Reforms) of 20 July 1612, appended to the hand-written statutes of 1599 and later to the printed ones of 1653, upheld the May 1608 provision acknowledging the chief physician's power to grant licences to those whom it described as 'inexpert' doctors to practise in places where there were no Coimbra graduates. The Reformações did not include the recommendation made by the crown-appointed reformer, Dom Francisco de Bragança (?-1634), that the Faculty of Medicine should use some of the funds in the Doctors' and Apothecaries' Chest to set up a college of physicians, a body that he believed would enhance the university's authority

\footnotetext{
${ }^{32}$ Estatutos da Universidade de Coimbra confirmados por el Rey nosso snör Don João o $4^{\circ}$ em o anno de 1653 (Coimbra: impressos por mandado de Manoel de Saldanha, officina de Thome Carvalho, 1654), III (título LI), 228-9.

${ }^{33}$ Braga, História da Universidade, II, 793.

${ }^{34}$ The term 'idiotas' was used in official documents for empirical practitioners, i.e. those who had learnt
}

their profession either in hospitals or, more often, by working under more experienced practitioners.

${ }^{35}$ Braga, História da Universidade, II, 794.

${ }^{36}$ lbid., 793.

${ }^{37}$ Silva, Collecção Chronologica, 1603-1612, 219 and 221-2. 
in its confrontation with the chief physician. ${ }^{38} / \mathrm{fn}>$ Instead, the university preferred to raise the salaries of the Faculty of Medicine teaching staff, who were paid less than their counterparts in the other faculties because they had so few students. In 1621, however, it went back on its decision and resurrected Bragança's proposal (which the crown only authorised eight years later and was never put into practice), claiming that there was a lack of doctors in the country 'both to treat and to read at the university'. ${ }^{39} / \mathrm{fn}>$ The need for this measure was even greater given that a royal act of that year (10 November 1621) forbade the hiring of New Christian teachers (at the university's request) and the Faculty of Medicine was still unable to attract students. ${ }^{40} / \mathrm{fn}>$

On the chief physician's side everything seemed to be going better after the 1608 charter. Not only did he continue to issue licences to practise medicine, but (as is evident from the reprimand he received on 15 November 1623) he felt strong enough to resist the royal orders he had been given in 1609 to travel around the country and examine people who were practising without a licence. ${ }^{41} / \mathrm{fn}>$ It was apparent that recognising foreign degrees was more remunerative and less inconvenient. Arguing that he had plenty to do in Lisbon, on 30 July 1678 the chief physician was authorised to appoint commissioners to carry out this task, which is likely to have increased his income significantly. ${ }^{42}$ / fn>

The chief surgeon-who was also a doctor-was more sheltered from the University of Coimbra's wrath, not because the institution considered his work more valid but, on the contrary, because it considered it less important, as mentioned. ${ }^{43} / f n>$ The university only really spoke out against surgeons when they were officially authorised 'to treat with medicine', and only the chief physician could do that, not the chief surgeon. That was an error of analysis, as will be shown below.

\section{Medical Career Paths or the Deconstruction of a Myth?}

Although the accusation brought against the chief physician and chief surgeon at the Évora Cortes in 1535-that they were endangering people's health for personal profitwas not backed up by factual evidence, the figures recorded in the royal chancelleries are revealing: between 1434 and 1495, 111 physicians and 183 surgeons had been examined, whereas in the following 40 years the numbers more than doubled, with 254

${ }^{38}$ On the importance of medical colleges, see, among others, Harold J. Cook, 'The History of Medicine and the Scientific Revolution', Isis, 2011, 102, 102-8.

${ }^{39} \mathrm{On}$ the resurrection of Bragança's proposal, see Silva, Collecção Chronologica, 1620-1627, 61; for the later authorisation, see Silva, Collecção Chronologica, 1627-1633, 133; on the fact that it was never activated, see Fernando Taveira da Fonseca, A Universidade de Coimbra (1700-1771). (Estudo Social e Económico) (Coimbra: Acta Universitatis Conimbrigensis, 1995), 230-31.

${ }^{40}$ The 1621 act was passed on the same day that New Christians were forbidden to leave the kingdom 'for fear of the autos de fé that had been ordered'. Silva, Collecção Chronologica, 1620-1627, 57.

${ }^{41}$ For this reprimand, see Ibid., 106.
${ }^{42}$ ANTT, Chancelaria de D. Afonso VI, 32, 116 (Charter granted to the chief physician Crispim do Rego).

${ }^{43}$ This attitude was not a Portuguese idiosyncracy. The opposite was true, however, in Groningen: Frank Huisman, 'Civic Roles and Academic Definitions: The Changing Relationship between Surgeons and Urban Government in Groningen, 1550-1800', in Hilary Marland and Margaret Pelling, eds, The Task of Healing. Medicine, Religion and Gender in England and the Netherlands-1450-1800 (Rotterdam: Erasmus Publishing, 1996), 69-100.

${ }^{44} \mathrm{On}$ the statistics for the physicians and surgeons examined, see Gonçalves, 'Físicos e Cirurgiões Quatrocentistas', 90. A lack of data for 1506-1510 means the figures are imprecise. Of the 254 medical licences 25 were licences 'to treat with medicine' 
medical licences (including 47 renewals by 1511) and 484 surgical licences (including 38 renewals by 1500 ) being issued. ${ }^{44}$

There are several possible explanations for this increase, in particular the publication of the Chief Physician's Statute in 1515. This was an inspection and control instrument that laid down severe penalties for transgressors-people who practised medicine without a licence. The crown wanted it implemented immediately, and that may have led to a wave of practitioners applying to be examined. But how can we account for the 110 medical licences and 175 surgical licences issued between the beginning of the reign of Manuel I (October 1495) and the date of the statute? The answer may lie in the treatment being meted out at that time to the Jews, who were traditionally associated with the medical arts, and the particular way in which the king dealt with the problem facing him. Around 100,000 of the Jews expelled from Spain in 1492 took shelter in Portugal, until in 1496 Manuel I fulfilled the clause included in the marriage contract he had signed with the daughter of the Catholic Monarchs, Ferdinand II of Aragon and Isabella I of Castile and ordered the expulsion of Jews and Moors from Portugal as well. In doing so, however, he attempted to safeguard the national interest, given the importance of Jews to the country's economy and society. Instead of decreeing that they should go at once, he gave them 10 months to either leave the country or convert to Christianity. He expected them to choose conversion, but it appears that that did not happen. To stem the flight of Jews before the final deadline, the king ordered that those who were still in the country be forcibly converted (and their children under the age of 14 be removed and raised by Christian families), assuring them that as New Christians they would be free from any religious inquisition for 20 years. In this context job legitimation and security was a powerful weapon, and the unusually large number of medical and surgical licences issued during Manuel I's reign may be due to the 'consistent policy of peaceful integration'$^{45}$ that he pursued. ${ }^{46}$

While the 1535 Cortes were suspicious of the miraculous multiplication of doctors and surgeons, the Studium Generale in Lisbon, which was going through a period of great instability, felt the competition particularly keenly, in part because it was unable to compete with other universities in Europe that continued to attract Portuguese teachers and students. In addition, even the Portuguese monarchs chose professionals trained abroad, especially in Montpellier, as their private doctors and, consequently, the chief physicians of the country. It was only in 1544 that Diogo Franco (before 1524-c.1554), the first locally trained chief physician, was appointed, having completed his studies at the Studium

and 229 doctors' licences. The chief surgeon licensed 484 surgeons in the same period, including 309 between 1515 and 1535. Data from the Medical Professions Database, 1430-1826.

${ }^{45}$ See João Manuel Vaz Monteiro de Figueiroa Rego, " A honra alheia por um fio": os estatutos de limpeza de sangue no espaço de expressão ibérica (sécs. XVI-XVIII)' (unpublished PhD thesis, Minho University, 2009), 23, quoting António José Saraiva, Inquisição e Cristãos-novos, 5th edn (Lisbon: Estampa, 1985), 34.

${ }^{46}$ The question of whether the empire put a strain on medical resources has yet to be analysed. Studies currently in progress suggest that officially recognised practitioners were not attracted to Portuguese North Africa and India in significant numbers in the first half of the sixteenth century. The situation in Brazil was different, but that colony only begins to appear regularly in the database in the eighteenth century. In any case, the dynamics of health care in the colonies differed considerably from the situation in Portugal itself, as will be demonstrated at a later date.

${ }^{47}$ There are some similarities with the status of Jewish doctors: although the trend was to exclude them from medical practice, their prestige assured them a 




Licences to 'treat with medicine' Doctors' licences

Fig. 1 Medical licences issued by the chief physician

Source: Data from the Medical Professions Database, 1430-1826.

Generale in Lisbon 14 years previously. ${ }^{47}$ The situation with regard to the chief surgeons was similar.

Analysis over the longer term reveals, however, that once the university had moved to Coimbra, and especially after 1550, the chief physician did curb his activities: while 365 licences for medical practice had been issued in the 55-year period 1495-1550, in the 276 years after 1550 only 1,371 were recorded-including the 633 licences issued by the Protomedicato, the body that replaced both the chief physician and the chief surgeon in 1782, which began its work with a nationwide clamp-down on unregulated practice (Figure 1). ${ }^{48}$ The number of doctors licensed over the period analysed (1495-1826) appears even less significant when compared with the other health care professions: whereas 5,789 licences were issued for apothecaries and 12,177 for surgeons, there were only 1,736 for medical practice. ${ }^{49}$ Rather more than half of these (882) were doctors' licences granting the title of medical doctor, while the other 854 authorised the holder 'to treat with medicine' ('curar de medicina'). Of the latter, 685 were awarded to surgeons and 169 to individuals who had put themselves forward for examination either on their own initiative or at the suggestion of the local council, as permitted by the chief physician's statute. Since 237 of the 685 licences awarded to surgeons were renewals, it follows that only 448 surgeons received licences 'to treat with medicine' over a period of more than 300 years. ${ }^{50}$

After its creation, the Protomedicato worked busily and greatly increased the number of licences 'to treat' that it issued, while the Faculty of Medicine in Coimbra found it difficult to implement the 1772 university reform promulgated by the Marquis of Pombal (1699-1782), which sought to give the university full control over health care, particularly

place in society and they even served as doctors to the Pope, at least until 1500. Park, 'Medicine and Society', 77.

${ }^{48} \mathrm{Of}$ the 633 licences issued by the Protomedicato, 570 were licenses 'to cure with medicine'. Data from the Medical Professions Database, 1430-1826.
${ }^{49}$ The 5,789 apothecary licences were awarded to 5,683 individuals; of the 12,177 awarded to surgeons, 127 were requested by physicians to practise surgery.

${ }^{50}$ All data from the Medical Professions Database, 1430-1826. 
that provided by empirical practitioners. The Protomedicato took advantage of the situation to try to reverse the royal directives and fulfil the chief physician's old ambition of overseeing Coimbra-trained doctors. It would be rash, however, to suggest that the positions of the two sides had changed, as Figure 1 appears to show. The end of the dual monarchy had certainly diverted many Portuguese students away from Salamanca to Coimbra, where average annual enrolments in the Faculty of Medicine rose from 65 between 1573 and 1654 to 147 from then until 1771, the year before the reform. ${ }^{51} / \mathrm{fn}>$ These were significant numbers, given the university's reputation for failing to keep up with the scientific revolution of the times and maintaining an old-fashioned, essentially theoretical approach. ${ }^{52} / \mathrm{fn}>$ Several highly regarded doctors, such as Luís António Verney (1713-92) and António Ribeiro Sanches (1699-1782), also fled the country at this time as a result of the fierce persecution of New Christians. The increase in enrolments may have been partly due to the near doubling of the value of the scholarships awarded to medical students (from 24,000 réis in the early years of the eighteenth century to 40,000 réis in 1729 for final-year students). ${ }^{53} / \mathrm{fn}>$ It is more difficult, however, to account for the virtual disappearance of licences 'to treat with medicine' for almost a century after 1675 . Might the requirements for practising medicine have become stricter, excluding those who did not have a university degree? There are two reasons why that cannot have happened.

The first is the fact that the university continued to complain of the great ease with which the chief physician 'made' doctors out of surgeons. But this complaint does not stand up to scrutiny: close examination of the licences awarded to surgeons to practise as physicians reveals the very restrictive conditions attached to them, both in geographical area-usually a single municipality and its 'boards' - and in the fields in which they could work. Most licences restricted their holders to the treatment of fever, pain (sciatica, stomach, kidneys, colic, etc.), 'common diseases of women', wounds (including cancers and lesions due to venereal disease), asthma and respiratory diseases. Only in two cases were 'surgeon-physicians' authorised to 'cure the mad, the manic and the melancholic'. They were allowed to handle and apply 'potions and roots' but forbidden to use compound remedies. ${ }^{54} / \mathrm{fn}>$

The available data also show that in institutional terms the chief physician did not authorise health care practitioners to work outside the main fields of their profession, particularly where the candidates they examined were mere amateurs ('curiosos'). In nearly all such cases they only issued licences for 'half surgery' (a sixteenth-century category), indicating that their recipients could only treat simple wounds, broken limbs and animal bites (from dogs, snakes or other creatures). Less frequently they were also allowed to bleed and purge, but only in the presence of an experienced surgeon. Such licences were exceptional: 'In the case of serious wounds to the head, chest and belly, the half-surgeon

\footnotetext{
${ }^{51}$ These averages are based on data in Antonio de Vasconcelos, Escritos Vários (Coimbra: Publicaciones do Arquivo da Universidade de Coimbra, 1988), II, 120-1. The numbers graduating show a similar trend, according to the medical partidos awarded to definite ex-Coimbra students: 59 in 1572-1654; 164 in 1655-1771; 245 in 1701-1800.
}

\footnotetext{
${ }^{52}$ Braga, Historia da Universidade, III (1700-1800), 139 et seq.

${ }^{53}$ Fonseca (A Universidade de Coimbra, 644-660) deals with the vicissitudes of this process.

${ }^{54}$ The words quoted here were standard expressions repeated on all the licences allowing surgeons to practise as physicians.
} 
may perform the initial treatment but not subsequent treatments, unless accompanied by a full (approved) surgeon. ${ }^{55} / \mathrm{fn}>$ Cases such as that of the late eighteenth-century Spanish surgeon José Francisco da Costa Herrera (before 1787-after 1819), who chose a secure position as a surgeon over a temporary one as a physician, occur several times in the period examined. ${ }^{56} / \mathrm{fn}>$ The importance of the location and the salary attached to the positions in question may account for such decisions. The important point here, however, is that gaining recognition as a physician may have been seen by some surgeons as a step on the way to consolidating their professional standing and not as an end in itself. The difficulties that surgeons faced in obtaining permanent positions as physicians can be expressed quantitatively: only seven such cases are recorded in our database in almost three centuries. In two other cases the appointments were qualified by the condition that they would terminate when 'a physician approved by the university arrives', as the law of the kingdom determined. The same condition applied to the 82 municipal surgeons who were granted licences 'to treat with medicine' in the same locality where they were employed as surgeons.

The second reason is one of timing: why would the chief physician have stopped issuing licences to treat with medicine just as the king granted him the privilege of appointing representatives to examine candidates locally (in July 1678)? A reasonable supposition, therefore, is that records were deliberately omitted, or perhaps even that the chief physician and his agents were manipulating the system for personal gain. Of course, some of these licences may have been registered with local councils, but by law their details should have been lodged with the chancelleries, as the Protomedicato began to do again in 1782. Ribeiro Sanches had raised suspicions about the agents' activities in the 1760s but there are no objective data to back them up. In this world of licences to treat with medicine and doctors' licences, the university's strategy was to spread the idea that there was no difference between the professionals licensed by the chief physician.

\section{Power Games and Conflicts of Interest: The Competitive Advantage of Salamanca}

The 'untaught and ignorant' label that the university used in 1606 to refer to doctors licensed by the chief physician had originally applied to surgeons and other professionals who were granted licences 'to treat with medicine', but it spread somewhat unfairly to its main competitors, foreign-trained physicians. ${ }^{57} / \mathrm{fn}>$ When the act of 12 May 1608 stated that 'physicians graduating from other universities than Coimbra' should be assessed by the chief physician in the same way as the 'unlearned', it paved the way for generalisations that soon entered official discourse. This discrimination, grounded in contempt for foreign universities, was intended to help Coimbra, where the Faculty of Medicine had long been fighting for survival, as the rector had clearly demonstrated to the king in August 1550. In the academic year then coming to an end, only seven doctors had received their licentiateships and seven bachelors had been examined. These figures

${ }^{55}$ Among many other examples, see ANTT, Livro das Ementas, book 2, 11.

${ }^{56}$ On Francisco da Costa Herrera, see ANTT, Ministério do Reino, mç. 438, cx. 548; Hosp. S. José,. 944, $151 v-152 v, 157 v-158 v, 169 v-170,173-173 v, 191-$ 191v, 235v. The Chancelaria de D. Maria I contains 32 different records on his career.

${ }^{57}$ The quote is from Silva, Collecção Chronologica, 1603-1612, 199. 
were in keeping with the very low numbers of students wanting to study there-11 in 1537 and 10 in 1540. Unless something were done soon, warned the rector, 'Your Majesty will not have a faculty of medicine in Coimbra. ${ }^{58} / \mathrm{fn}>$

The Faculty of Medicine was not the only one with recruitment difficulties, but it was the worst affected. The 'honours and freedoms' that the monarch had awarded to students at the University of Coimbra in 1538 to make it more attractive-copying measures applied long before in Paris, Oxford, Bologna and elsewhere-were failing to produce the desired effects. In addition, the Coimbra degree was (according to a provision of 16 October 1541) being used fraudulently by students who started their studies in Coimbra and finished them in Salamanca, where they were only asked for 'the proof of courses of students from Coimbra'. ${ }^{59} / \mathrm{fn}>$ thereby ensuring they would receive the privileges awarded by the 1538 act when they returned to Portugal. ${ }^{60} / \mathrm{fn}>$ The king tried to make students studying in Salamanca return to Portugal on more than one occasion (in 1556, 1564 and 1575 at least) and ordered the academic authorities in Coimbra to grant them credit for all the disciplines they had taken there, even though from 1559 onwards the university statutes only allowed equivalence to be granted for licentiate courses taken abroad. ${ }^{61} / \mathrm{fn}>$

The lack of precise information on the number of graduates coming out of Coimbra prior to 1700 makes it impossible to compare the two 'producers' of doctors (the university and the chief physician) directly, but the figures for 1537, 1540 and 1550 give important clues to the difficulties experienced by the Faculty of Medicine, particularly in comparison with the 86 doctors licensed by the chief physician between those dates (see Figure 1). Fifty-seven of these had bachelors' degrees and had therefore received academic training, nine of them in Salamanca. ${ }^{62} / \mathrm{fn}>$ According to Joaquim Veríssimo Serrão, the Portuguese had little faith in the 1537 reform, even after Pope Paul II's bull of February 1539 had granted Coimbra graduates the same privileges as those from Salamanca. ${ }^{63} / \mathrm{fn}>$ The effect that all of this had on the chief physician's activity was not linear, however, especially after 1550, when the numbers of Portuguese students going to Salamanca increased.

What can explain the fluctuations in the chief physician's activity during the Iberian Union, particularly in the late sixteenth and early seventeenth centuries, just as the numbers of Portuguese students in the Salamanca medical faculty were at their peak? ${ }^{64} / \mathrm{fn}>$ In fact, between 1579 and 1639 more studied medicine there, on average, than in Coimbra.

\footnotetext{
${ }^{58}$ ANTT, Corpo Cronológico, Pt I, mç. 84, no 136.

${ }^{59}$ Martín, Salamanca y Coímbra, 419.

${ }^{60}$ ANTT, Corpo Cronológico, Pt I, mç. 84, no 136.

${ }^{61}$ For 1556 , see Teixeira de Carvalho, 'A anatomia em Coimbra no século $\mathrm{XVI}^{\prime}$, Revista da Universidade de Coimbra, 1914, 3, 265, doc. 25; for 1564, see Ibid., 258. In 1575 the decision to bring students back was extended to other Spanish universities. This was more for political reasons and to protect Coimbra University than for cultural reasons. Credit was granted provided the students presented themselves in Coimbra by 1 October, the first day of lectures.
}

\footnotetext{
${ }^{62}$ Arquivo da Universidade de Coimbra, Índice de Alunos da Universidade de Coimbra, António Vaz. During the same period, the chief physician had issued 19 licences 'to treat with medicine'; the disproportion is clearly visible in Figure 1.

${ }^{63}$ Joaquim Veríssimo Serrão, Portugueses na Universidade de Salamanca (Lisboa, 1962), 135 et seq.

${ }^{64}$ The year 1633-34 stands out, when Portuguese students accounted for 69 of the 108 enrolments recorded.
} 


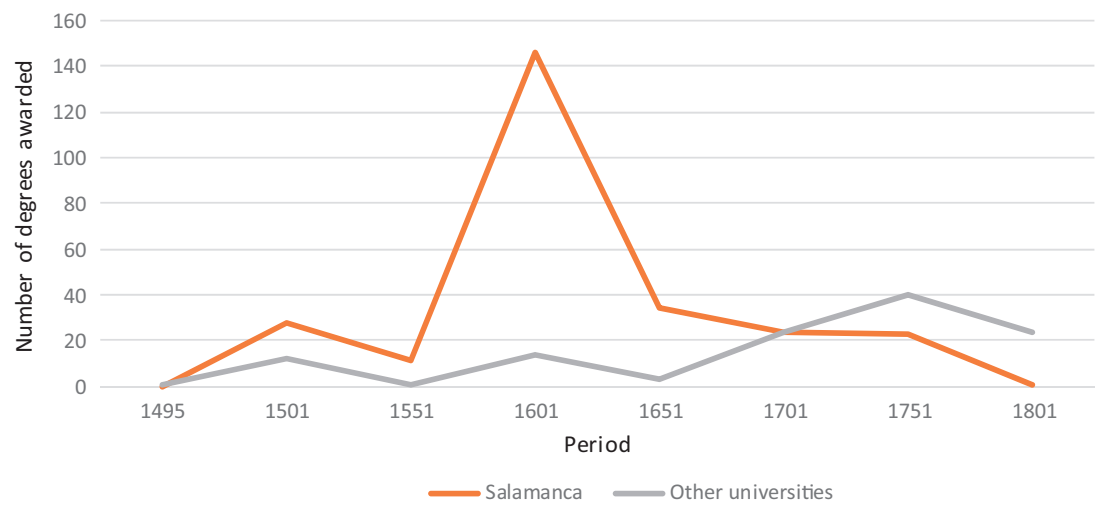

Fig. 2 Medical degrees awarded to Portuguese students by different universities Source: Data from the Medical Professions Database, 1430-1826.

Some writers, such as Ángel Marcos de Dios, hold that Salamanca was attractive not only because of its closeness and its prestige but also because the majority of the Portuguese students that chose that university were New Christians, who felt safer there as the Inquisition tightened its grip in Portugal. ${ }^{65} / \mathrm{fn}>$ Yet, as Noemí Cubas Martín has pointed out, this was not the only or even the main cause of the variation. ${ }^{66} / \mathrm{fn}>$ Of the several reasons she assesses, using data from Veríssimo Serrão and Marcos de Dios, one in particular stands out: the fraudulent methods people employed to obtain degrees, which the 1538 statutes had attempted to stamp out. Arts and medicine were the worst affected courses according to Veríssimo Serrão, and Martín shows that some students even managed to graduate in both on the same day. ${ }^{67} / \mathrm{fn}>$

In our own data, Salamanca's dominance as the main producer of Portuguese medical graduates is indisputable, but the timing is slightly different (Figure 2).

Based on the 322 medical licences that stated the name of the university that had awarded the applicant's degree (out of the 659 doctors who had certainly been trained abroad), Salamanca was by far the most important with 228 doctors (70 per cent); the actual number must have been considerably higher, given the proportion of licences that did not mention the applicant's university by name. But why did the number of foreigntrained graduates licensed by the chief physician only rise after 1600, and not after 1580 ? The reason seems to lie in his relations with the university, as discussed above, and the king's rejection of their agreement regarding medical graduates of foreign universities.

It is well known that religious intolerance in Portugal led many New Christian doctors to flee. Such factors should not be underestimated, since there is abundant evidence that Old Christians were gaining strength in situations where they could take direct action on this issue, as in the Court of the Inquisition, where many doctors and surgeons were denounced (and condemned) as New Christians and so forced to give up their

${ }^{65}$ Marcos de Dios, 'A Universidade de Salamanca', 91. $\quad{ }^{67} \mathrm{Ibid} ., 358-9$.

${ }^{66}$ Martín, 'Salamanca y Coímbra', 550 et seq. 
positions. ${ }^{68} / \mathrm{fn}>$ Yet the issue was in fact much more complex. There was certainly a struggle between Old and New Christians, but there was also a fight over jobs and positions of power. These attitudes of the university and the chief physician, which were based essentially on protecting their own interests in terms of income and social prestige - which often go together-have been ignored by historians. ${ }^{69} / \mathrm{fn}>$

Something that cannot yet be explained is the relation between the reduction in the number of doctors' licences and the increase in licences 'to treat with medicine' that were issued between 1575 and 1600 . While this might be due to the chief physician seeking compensation for a hypothetical fall in income after he accepted a fixed sum of 200 cruzados a year instead of one silver mark for every doctor he licensed, it also cannot be ruled out that he had started issuing licences 'to treat with medicine' to people with academic training. This possibility is supported by the fact that the university did not try to replace the chief physician for leaving foreign-trained doctors unexamined-after all, its objective was to remove the competition, not to feed it. It should also be noted that the number of licences 'to treat with medicine' fell after the king put an end to the informal agreements between the chief physician and the university, and doctors' licences rose.

This new wave of doctors after 1615 is very likely to have included some of the 'medical students who were practising around the country without having done their exams', as Thomas Serrão, reader in the Faculty of Medicine, complained in the statement he made to the Board of Enquiry set up in 1619 during the reform of the university. ${ }^{70} / \mathrm{fn}>$ Even so, as mentioned above, most of the doctors licensed by the chief physician after 1600 were from Salamanca. This situation cannot have been entirely displeasing to the Spanish monarch, since these Portuguese students were to some extent helping to mitigate the decline of Salamanca, which had rapidly been losing both prestige and students since the end of the sixteenth century. The king in Madrid was quicker to challenge the agreement between the university and the chief physician than to respond to the university's proposals to fill several chairs in the Faculty of Medicine, some of which had been vacant for many years. ${ }^{71} / \mathrm{fn}>\mathrm{In}$ a context of widespread corruption involving irregularities in examinations, the sale of false certificates, bribery in the awarding of scholarships, absent and poor-quality teachers, fierce persecution of New Christian staff and fighting over the chairs they left vacant, many Portuguese students preferred to go to Salamanca, where they could at least be sure that the medical curriculum was shorter. Or they began studying in Coimbra and then turned to the chief physician to achieve by practical examination the qualification that they would take much longer to achieve via the academic route. $^{72} / \mathrm{fn}>$

\footnotetext{
${ }^{68}$ The work of Timothy Dale Walker is essential reading for this, in particular Médicos, medicina popular e Inquisição: a repressão das curas mágicas em Portugal durante o lluminismo (Rio de Janeiro; Lisbon: Fiocruz; Imprensa de Ciências Sociais, 2013).

${ }^{69}$ As demonstrated in Laurinda Abreu, 'A organização e regulação das profissões médicas no Portugal Moderno: entre as orientações da Coroa e os interesses privados', in Adelino Cardoso, António Braz de Oliveira and Manuel Silvério Marques, eds, Arte
}

médica e imagem do corpo: de Hipócrates ao final do século XVIII (Lisbon, Biblioteca Nacional de Portugal, 2010), 97-122.

${ }^{70}$ Braga, História da Universidade, II, 781,

${ }^{71} \mathrm{lbid}$., 526 et seq.

${ }^{72} \mathrm{~A}$ prosopographical study is needed to account for the great divergence between the number of students who enrolled in the Faculty of Medicine and the number who completed their medical studies there. Luís Gonçalves is currently working on this 


\section{Building Monopolies: partido Doctors and the Dominance of Surgeons}

It is an accepted fact that the number of practising health care professionals who held a university medical degree in the early modern period was very small. Katharine Park reports that the proportion of university-educated practitioners was roughly one-third in late medieval Florence but only about 10 per cent in sixteenth-century England. ${ }^{73} / \mathrm{fn}>$ The situation in Portugal was no different, although the ratio of academics to empirics here seems to have been even more unbalanced.

Between 1579 and 1640 the Faculty of Medicine at the University of Coimbra cannot have matriculated more than 770 students, including both new and returning students. This average of less than 13 per year was slightly lower even than that calculated for the period 1567-80 and shows that the faculty was still finding it very difficult not only to attract students but also to award the 30 scholarships planned in 1568. Documents produced by some university members hint at the corruption that soon insinuated itself into the allocation of these scholarships and the management of the money collected in the Doctors' and Apothecaries' Chest. Detailed research into the university's finances would be needed to validate this information and perhaps confirm what a few isolated indicators appear to suggest, which is that, despite all the problems that may have existed, the Faculty of Medicine's survival in the early modern period was due to the scholarship money it received from the municipalities.

One thing that is certain is that the university used the scholarships as an argument to try to monopolise the medical partidos (public appointments) offered by local councils and central government. Since King Sebastião's original document creating these scholarships was missing, as previously mentioned, it is conceivable that what may have been just a suggestion - that former scholarship holders be preferred for these posts-was turned into an obligation. This hypothesis is supported by two letters signed by CardinalKing Henrique (1512-80) and dated July 1578, which were ratified and forwarded to Évora City Council by his successor Filipe I in 1584 and 1585. In the first, Henrique acknowledged the existence of the medical scholarships set up by King Sebastião and showed his interest in continuing the project, recommending that the council should award the partido of 'health physician of the city' to an Old Christian doctor who had held one of those scholarships; if they had difficulty in finding one, they should ask the university for help and, if one could still not be found, they should give the partido to whomever they preferred. ${ }^{74} / \mathrm{fn}>$ The second missive was identical except that it referred to apothecaries, and it was even clearer regarding the employment of scholarship holders: 'I have had letters sent to the councils and misericórdias of certain cities and towns of these my kingdoms strongly recommending to them that the partidos made for apothecaries should be given to the Old Christian apothecaries of said number [i.e. scholarship holders] who have already finished their studies at said university. ${ }^{75} / \mathrm{fn}>$

Three important points emerge from these documents. In the first letter, it is at least implicit that the crown would accept the appointment of New Christians to public

question for his doctoral thesis, mentioned previously.

${ }^{73}$ Park, 'Medicine and Society', 80.
${ }^{74}$ On King Sebastião's medical scholarships, see Arquivo Distrital de Évora (ADE), Livro I dos Originais, no $71,177$.

${ }^{75} \mathrm{ADE}$, Livro $V$ de Registo, no 139, 60-61. (23 December 1585). 
positions-as a last resort, of course, but they would be authorised. The second letter shows that it was in fact King Sebastião and not Filipe II who established scholarships for apothecaries. Finally, both letters merely suggest that scholarship holders should be given priority for local partidos. ${ }^{76} / \mathrm{fn}>$ When in 1604 this idea was transposed into the Doctors' and Apothecaries' Statute it was made mandatory: 'they [doctors who had graduated from Coimbra] and not any others shall have the partidos of the cities, towns, councils, hospitals and misericórdias that exist in the kingdom ... and they shall also have the partidos of the Court of Appeal and the Porto Court of Appeal and other courts, and I urge the prelates and ecclesiastical communities to give them their partidos' ${ }^{77} / \mathrm{fn}>$ The importance of this decision was reinforced in the next clause, in which the crown promised to endow the rector with the authority to force council, hospital and misericórdia officials to give their partidos to these scholarship holders.

At that time, in 1604, the university and the chief physician were trying to persuade the king to accept the agreement they had reached, after he had rejected it in 1596. The assertiveness of the 1604 statute was another step towards strengthening the university's position.

How did society put these decisions into practice? The geographical distribution of partidos is of interest (Figure 3).

The first point to note is that although local council partidos had existed since the Middle Ages, they only became really significant after the Coimbra University scholarship system was implemented in $1568 .^{78} / \mathrm{fn}>$ Secondly, while the initial aim of the scholarship scheme was only to provide doctors and apothecaries, local councils took the opportunity to request non-academically trained surgeons as well, albeit in smaller numbers, making up the standard trio of health care professionals in many places. ${ }^{79} / \mathrm{fn}>$ Thirdly, there were areas of the country (such as Trás-os-Montes) where formal medical care was provided almost solely by surgeons. Fourthly, while the king's original aim of providing medical care in the poorest and most vulnerable regions, particularly in the interior of the country (where most of the municipalities that paid for the scholarships were located), was actually fulfilled in the early years of the scheme, as I have demonstrated elsewhere, the partidos soon began to be concentrated along the coast and in the economically more prosperous areas of the centre and north. ${ }^{80} / \mathrm{fn}>$ That such towns were more

\footnotetext{
${ }^{76}$ Fonseca (A história da universidade, 658) mentions a royal order of the same date (23 December 1585) that makes it mandatory to prioritise scholarship holders.

${ }^{77}$ Silva, Collecção Chronologica, 1603-1612, 219, 46.

${ }^{78}$ On local council partidos in the Middle Ages, see Iona McCleery,'Medical licensing in late-medieval Portugal', in W. J. Turner and S. M. Butler, eds, Medicine and Law in the Middle Ages (Leiden: Brill, 2014), 196-219.

${ }^{79}$ Although six scholarships were established by royal order on 18 October 1616 for surgeons to study at the University of Coimbra, only one partido surgeon (in 1811) mentions having learnt speculative medicine there. This refers to health care professionals as partido holders, that is. Local councils also gave licences to a wide variety of other professionals in par-
}

allel, as happened throughout Europe. See Margaret Pelling 'Occupational Diversity: Barber Surgeons and the Trades of Norwich, 1550-1640', Bulletin of the History of Medicine 1982, 56, 484-511.

${ }^{80}$ Huisman found a similar situation pertaining to providing medical care in the poorer regions, but restricted to Groningen: Huisman, 'Civic Roles', 92. Scattered examples have also been found in some German cities. For later periods, see Teresa Ortiz et al., 'Health Professionals in Mid eighteenth Century Andalusia: Socioeconomic Profiles and Distribution in the Kingdom of Granada', in John Woodward and Robert Jutte, eds, Coping with Sickness. Historical Aspects of Health Care in a European Perspective (Sheffield: European Association for the History of Medicine and Health Publications, 1995), 19-44. For France, see Jean- 


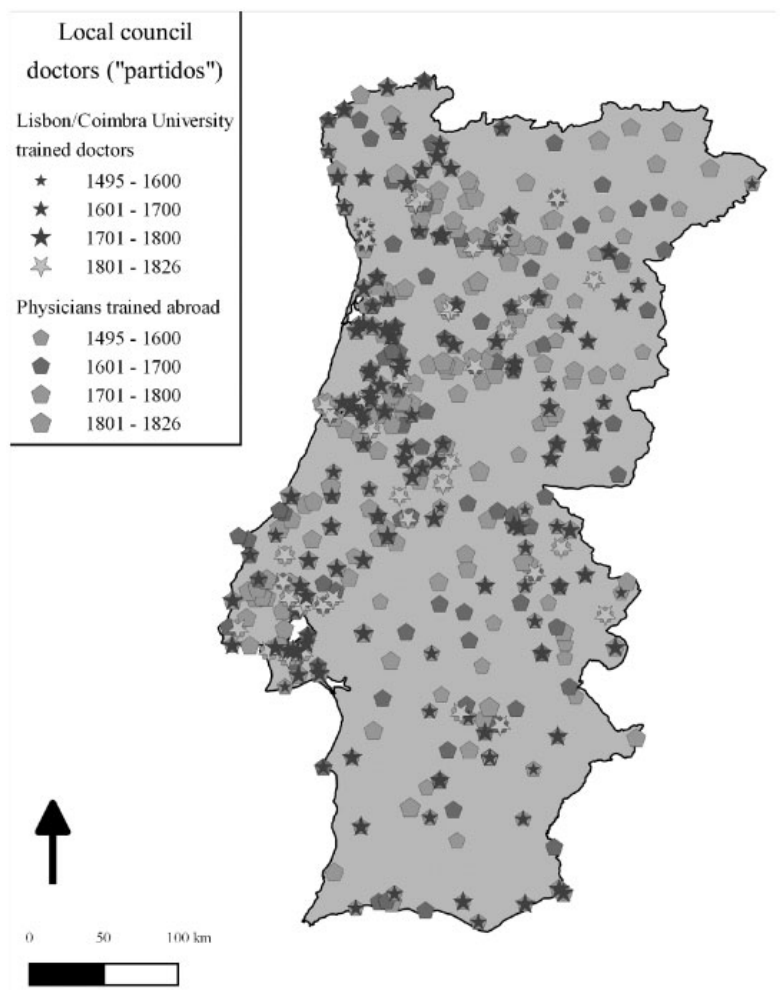

Fig. 3 Local council health care appointments (partidos)

Source: Data from the Medical Professions Database, 1430-1826.

attractive and could offer higher salaries was one reason why the crown's plans were foiled. But it was not the only one: when Fernando Tavira looked at where doctors licensed between 1700 and 1771 were from, he found that 66.7 per cent were from Coimbra and its surrounding area, which may confirm the accusations made at the time that the university was selling Faculty of Medicine scholarships. ${ }^{81}$

While the university did not seem to be concerned about the unbalanced distribution of health care professionals, it did worry about where doctors in particular had been trained. In this regard, it had no doubt that New Christians with degrees from Salamanca were monopolising the partidos. At the root of the problem was the chief physician, who licensed them, although the university never actually made the connection between the chief physician and the New Christians, perhaps because in many cases he himself had taught in the Faculty of Medicine. In the Cortes, the people's representatives complained that 'most doctors, and apothecaries and surgeons, are New Christians, and also of little

Pierre Goubert, 'Réseau médical et médicalisation en France à la fin du XVIlle siècle', Annales de Bretagne et des pays de l'ouest, 1979, 86, 221-29.
${ }^{81}$ The figures for Coimbra are from Fernando Taveira da Fonseca, 'The Social and Cultural Roles of the University of Coimbra (1537-1820). Some Considerations', e-JPH, 2007, 5, 229 et seq. 
knowledge, as is well known, and in their power the lives of ordinary people are in great danger' (Lisbon, January 1641)..$^{82 / f n>~}$

According to a statement made at the 1645 Cortes, 'there is a great lack of Old Christian doctors and so that it may be remedied, we ask Your Majesty to please honour those who study [at] this faculty'. ${ }^{83} / \mathrm{fn}>$ Although the author of the statement has not been identified, it raises strong suspicions that the University of Coimbra itself was using the Cortes as an opportunity to address the king in the name of the people. However, it cannot have been easy for the university to explain away its contradictory position when it had tried to reduce the number of scholarships in order to increase the value of each one-a move that the king blocked in May $1632 .{ }^{84} / \mathrm{fn}>$

The university appeared to have some reason to complain, however, considering the number of partidos held by foreign-trained doctors. Of the 1,164 medical partidos in the municipalities that were awarded (to 1,045 doctors) between 1495 and 1826, we have so far been able to identify only 350 as being held by doctors trained in Coimbra. Since 110 of these awards were renewals, the university only managed to place 299 doctors in more than three centuries (Table 1). Even if the data given in Table 1 are later revised in favour of the university, they show that the chief physician was a major competitor in terms of placing his doctors in partidos, at least in the period 1585-1640: 38 of the 61 doctors who took up partidos had graduated from Coimbra, while 23 had gained their 'qualification' from the chief physician. It may be noted, however, that the number of partidos held by doctors licensed by the chief physician is smaller than the number of the doctors themselves. This may mean that some of the doctors were appointed only temporarily or were replaced. Only future studies will be able to help clarify this.

Since the councils would tell the king the names of the doctors they wanted to hire, the only possible conclusion is that communities deliberately ignored Coimbra graduates. These choices raise a number of questions for further research, two of which are particularly relevant. First, were these communities hiring locally born doctors? That seems likely, because the data show that doctors trained in Coimbra tended to move further from home than those trained abroad. ${ }^{85} / \mathrm{fn}>$ Moreover, when on 4 June 1624 the king authorised the creation of a partido for a doctor in Guarda, he specified that the doctor appointed to it should provide free treatment for the friars of Saint Francis and all the poor people within the hospital and outside, adding that 'this same obligation shall be placed henceforth on similar partidos granted anywhere in the kingdom'. ${ }^{86} / \mathrm{fn}>$ This warning implies that doctors trained in Coimbra may not have been fulfilling their obligations,

\footnotetext{
${ }^{82}$ Braga, Historia da Universidade, II, 803.

${ }^{83}$ Capitulos gerais apresentados a elRey D. João nosso senhor IIII deste nome, XIIII Rey de Portugal, Nas Cortes celebradas em Lisboa com os tres Estados em 28 de Janeiro de 1641. Com suas Repostas de 12. de Sete[m]bro do anno de 1642. No 2. do seu Reynado, \& 38. de sua idade. Com as replicas, repostas, \& declarações dellas em 1645._-Por mandado de S.M. \& ordem do D. Thome Pinheiro da Veiga do seu Conselho .... -Em Lisboa : por Paulo Craesbeeck, 1645, fl. 14.

${ }^{84}$ Braga, Historia da Universidade, II, 810.
}

\footnotetext{
${ }^{85}$ This conclusion is to some degree corroborated by Table 1: Coimbra-trained doctors tended to practise in more than one place, unlike those licensed by the chief physician, who were rehired more often in the same place. The data used to plot the maps also show that the chief physician's doctors used to practise in their place of origin, while Coimbra graduates tended to be spread out more widely across the country. Corruption in the awarding of scholarships, as studied by Fernando Taveira da Fonseca (mentioned below), may also help to explain this difference.

${ }^{86}$ Silva, Collecção Chronologica , 1620-1627, 122.
} 
Table 1 Doctors appointed to partidos, 1495-1826

\begin{tabular}{lcccc}
\hline Period & \multicolumn{4}{l}{ Number of doctors appointed (total number of partidos held) } \\
\cline { 2 - 5 } & Coimbra graduates & Licensed by the chief physician & Unknown origin & Total \\
\hline $1495-1579$ & $0(0)$ & $7(7)$ & $26(27)$ & $33(34)$ \\
$1580-1640$ & $38(41)$ & $23(20)$ & $123(132)$ & $184(193)$ \\
$1641-1700$ & $41(46)$ & $12(6)$ & $76(91)$ & $129(143)$ \\
$1701-1781$ & $117(135)$ & $10(6)$ & $155(174)$ & $282(315)$ \\
$1782-1826$ & $103(128)$ & $9(8)$ & $305(343)$ & $417(479)$ \\
Total & $299(350)$ & $61(47)$ & $685(767)$ & $1045(1164)$ \\
\hline
\end{tabular}

Source: Data from the Medical Professions Database, 1430-1826.

which included providing free medical care for the poor. That does not mean that doctors trained abroad carried out their professional duties any better, but Coimbra graduates had studied at the expense of municipal funds. Fernando Taveira da Fonseca reports complex eighteenth-century lawsuits between doctors who had held scholarships at Coimbra and wanted to take up posts that they considered theirs by right and local authorities that backed their 'own' doctors licensed by the chief physician. The disputes became so bitter that eventually, on 9 July 1751, the king decreed that it was no longer obligatory to hire Coimbra-trained doctors, although they should be given preference. ${ }^{87} / \mathrm{fn}>$ This return to King Filipe I's suggestion of 1585 meant that Coimbra had lost again, and this may help to explain the sudden rise in licences 'to treat with medicine' shown in Figure 1.

Were the 746 non-Coimbra-trained doctors (Figure 4) (as well as surgeons-Figure 5) and apothecaries who held partidos actually New Christians, as the University of Coimbra claimed? It is unlikely, but only the prosopographical studies currently under way will be able to prove it.

It is clear, however, that by focusing both on protecting the doctors it trained, through attempting to keep a monopoly over the jobs available in local government and in various central government bodies, and on protecting the rights and privileges of its teaching staff, the Faculty of Medicine in Coimbra not only lost the battle of modernisation but was also unable to see the real challenge facing medicine, which was the rise of surgeons. Between 1496 and 1826, the chief surgeon issued 12,712 licences to 12,533 individuals, whereas in Granada in 1751-54 they made up 13.5 per cent of the 1,358 professionals, just 0.3 percentage points more than physicians. ${ }^{88} / \mathrm{fn}>$ They were the ones who actually controlled the field of medicine in Portugal, as they did in many other countries.

\footnotetext{
${ }^{87}$ Fonseca, A Universidade de Coimbra, 660-9.

${ }^{88}$ The Coimbra data are from the Medical Professions Database, 1430-1826; for the Grenada figures, see Teresa Ortiz et al., 'Health professionals', 21. Huisman ('Civic Roles', 92) suggests the proportion of surgeons in sixteenth-century Groningen was similar to that in the seventeenth-20 surgeons for a
}

population of 20,000 - comparable to the density in Norwich, England, of approximately 1:450 (M. Pelling and C. Webster, 'Medical Practitioners', 2256). Essential reading on this subject is Sandra Cavallo, Artisans of the Body in Early Modern Italy: Identities, Families and Masculinities (Manchester: Manchester University Press, 2007). 


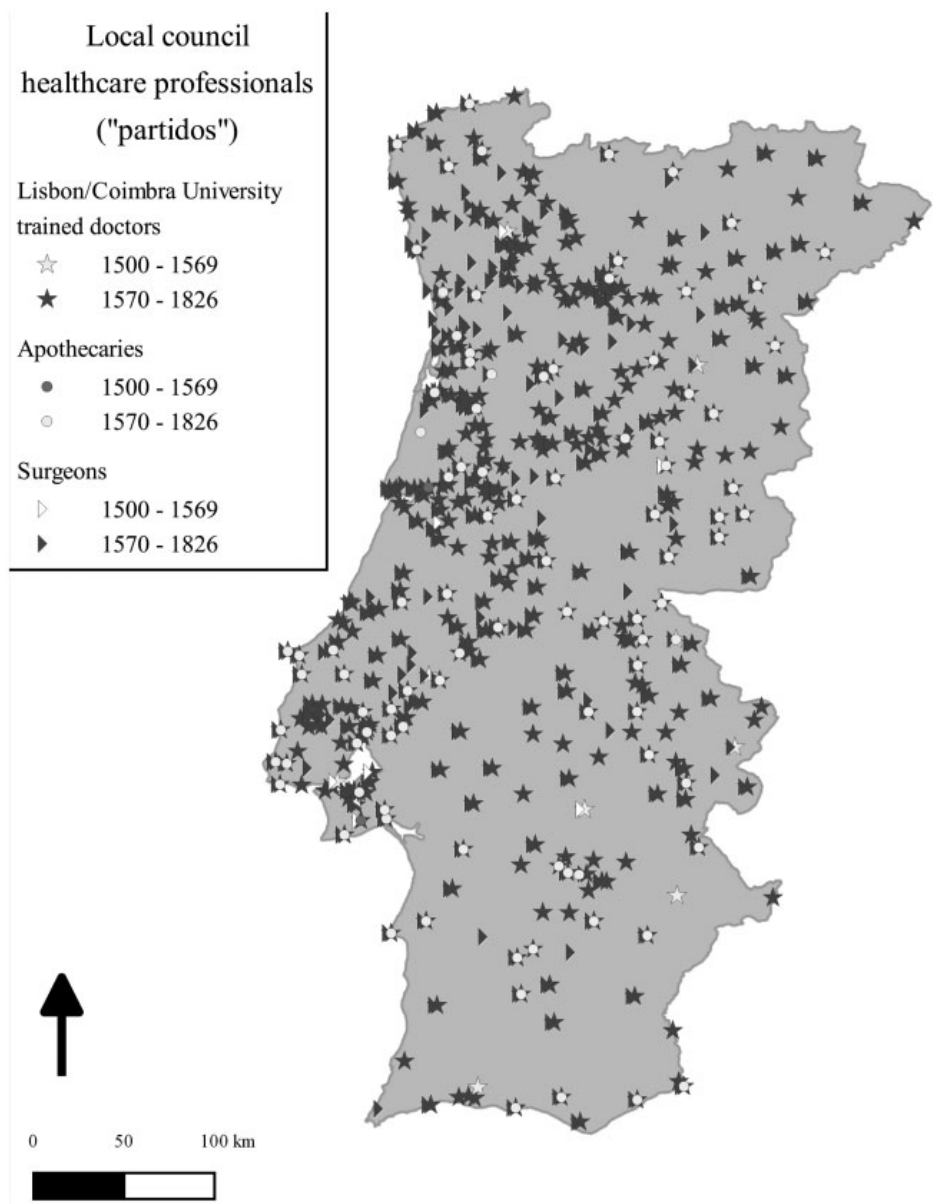

Fig. 4 Distribution of doctors appointed to partidos

Source: Data from the Medical Professions Database, 1430-1826.

The dominance of surgeons in Portugal was 'demonstrated' from Paris in the 1760s by António Ribeiro Sanches, the best-known Portuguese Enlightenment physician. He very strongly criticised the 'four sorts of men' who operated in the medical field-physicians, surgeons, bloodletters and apothecaries - none of whom had appropriate training, and complained that as soon as a surgeon received his licence, he would set himself up in a village or a town ready to work as a physician and apothecary. Without explaining the statistical basis for his theory, Ribeiro Sanches claimed that only 5 patients out of 100 needed minor surgery (for 'bloodletting, lancing boils or mending legs or arms') and only 15 patients out of 300 required 'more complex surgical operations'. The rest needed medical care. Thus, when surgeons were called out they tended to do the work of physicians. Of course, had they refused to do so they would not have been able to survive. 




Fig. 5 Distribution of locally appointed surgeons

Source: Data from the Medical Professions Database, 1430-1826.

Ribeiro Sanches came to a damning conclusion: 'The State has established a school of surgery, and a Chief Surgeon, to authorise a surgeon to spend his life practising ... medicine, which he has never learnt.' Even worse was the situation in small communities of few people and fewer resources, where medical help was reduced to barber-bloodletters, who were forced by the circumstances to act as both physicians and surgeons. The care they gave was 'useless, sometimes even fatal, relying entirely on bloodletting'. ${ }^{89} / \mathrm{fn}>\mathrm{Not}$ only were surgeons more readily accepted by the people than physicians, they were less expensive and could still use the same remedies and curative techniques. According to popular accounts, surgeons were the first to be called out in the event of illness. The situation was well known to physicians, who complained that when they arrived at a

${ }^{89}$ António Nunes Ribeiro Sanches, Obras, 2 (Coimbra: Imprensa da Universidade, 1966), 48-9. 
patient's home only to find that a medical case was almost lost, it was impossible to tell whether the patient's state was due to the original disease or to the surgeon's treatment. ${ }^{90} / \mathrm{fn}>$

\section{Final Remarks}

This contribution has attempted to assess the impact that the private and/or corporate interests of the authorities who validated doctors' qualifications had on the organisation of health care professions throughout the early modern period. It has looked at doctors trained academically in Coimbra or foreign universities and people without university degrees who were awarded doctors' licences or licences 'to treat with medicine'. Doctors with degrees from Coimbra were regulated by the University of Coimbra, whereas the others depended on the chief physician. Both the university and the chief physician answered directly to the king. The discussion began with the reforms that the crown instituted in the early sixteenth century to regulate medical training and health care practice. One of the most significant of these measures was the decision to increase the number of years required to train a doctor, which made the Coimbra medical curriculum one of the longest, if not the longest, in Europe. This resulted in added difficulties for the university, which was already struggling to attract and keep students in the Faculty of Medicine. In the search for shorter and less expensive degrees, Portuguese students set off en masse for foreign universities, especially Salamanca. Some of them even went there just to be awarded a degree, for which they merely needed to demonstrate that they had taken some subject courses in Coimbra, in the knowledge that their degrees would be recognised by the chief physician once they returned to Portugal.

The University of Coimbra tried in vain to have this prerogative of the chief physician's revoked. The king resisted the university's demands in an attempt to maintain some balance between the two authorities and also for pragmatic reasons, since it was widely known that the university was finding it difficult to train doctors. For that reason, the chief physician was also granted the authority to recognise empirical skills in certain specific cases and to give such practitioners the same status as doctors. What was at stake was not so much the multiplication of officially recognised health care professionals, but the regulation of a highly competitive and complex market, a task that the king entrusted to his foremost doctor.

These last powers granted to the chief physician were the basis for the University of Coimbra's attacks on him. In doing so, it lumped together as 'untaught and ignorant' those practitioners who were being given 'licences to treat with medicine' and doctors who had been properly trained abroad or who had had at least some university education. By licensing individuals with a wide range of levels of knowledge, the chief physician was discrediting the medical profession, and by questioning the credibility of the doctors licensed by the chief physician, the university was claiming to be the sole guardian of accredited knowledge.

\footnotetext{
${ }^{90}$ This discussion on Ribeiro Sanches and his views on surgeons is developed in greater detail in Laurinda Abreu, Public Health and Social Reforms in Portugal (1780-1805) (Newcastle upon Tyne, Cambridge
}

Scholars Publishing, in press); and in Pina Manique: um reformador no Portugal das Luzes (Lisboa, Gradiva, 2013), 79-80. 
This narrative became established at the turn of the sixteenth to the seventeenth century, when Filipe I rejected an informal agreement that the university and the chief physician had reached a few years previously, whereby the former would pay the latter a certain amount for him to refrain from issuing doctors' licences. The fact that while the agreement had been in force the university had not started examining doctors trained outside Portugal suggests that it believed that ignoring the obstacle would make it go away.

The university's strategy was based on the assumption that the chief physician was the principal cause of all the ills affecting the Faculty of Medicine, but it concealed two major problems that it was unable to solve. The first was that the medical curriculum was socially unappealing, as it mostly attracted members of the lower echelons of society. This situation was exacerbated with the introduction of a measure designed to guarantee student numbers - the creation of local council-financed scholarships by royal order in 1568. In fact, the king decided in 1578 that scholarships should preferably be awarded to candidates from the contributing municipalities, and these were mostly poor areas that were being forced to invest in health care resources, as I have demonstrated elsewhere. Leaving aside the problems in implementing this decision, the mere fact that the Faculty of Medicine depended on having scholarship students was an indication of its recruiting ability.

Another problem, which may partly account for the one above, concerns student expectations regarding the professional return they might enjoy on the investment made in their training. It was public knowledge that medicine was unable to compete with the other faculties, notably law, whose graduates could compete for lucrative careers in the local branches of central government. Graduates in medicine had fewer prospects, and so the university sought to monopolise partidos in the municipalities and central government bodies for their benefit. This move culminated in the royal order of 1608, in which the king agreed that doctors licensed by the chief physician should be passed over in cases where Coimbra graduates applied for a post. In this respect, while the university had never banned New Christian students from entering the Faculty of Medicine, it did make effective use of the purity of blood policies to remove New Christians from medical partidos, and a religious stigma began to be associated with doctors licensed by the chief physician. However, between the rule and its implementation stood the local councils that hired the doctors and often paid their salaries. Their vehement insistence on their right to choose their own candidates without prioritising Coimbra graduates eventually won recognition in 1751, when the crown abolished the 1608 requirement to hire doctors who had held scholarships.

The Faculty of Medicine did not only have its graduates to worry about, however. Its teaching staff, too, had expectations, some of which were very difficult to meet. While its expulsion of New Christian teachers was in step with the kingdom's general policy of religious intransigence at that time, the university was less able to influence the monarch's choice of chief physician and chief surgeon, posts that in the early eighteenth century readers in the Faculty of Medicine were eager to fill. As the university itself acknowledged at the time, these were the appointments most sought after by members of that faculty since they did not have 'the prospects or the expectations of readers in the other faculties'. These posts were coveted not only for themselves but also for the doors 
and avenues that they opened up, leading in particular to positions in Todos os Santos Hospital, the Court of Petitions and the Inquisition Prisons, if not even a peerage. In short, the posts that the readers in medicine considered most prestigious were precisely those that offered the greatest competition to the institution where they were teaching. It was for these posts that they fought so hard during the period in question. That is not to underestimate the importance of religious and scientific beliefs in these processes, although there is good evidence that in many cases they were used to advance much more prosaic personal interests. However, reliable data in this field will only be forthcoming once we have reconstructed a significant number of life courses, and that may require the addition of further documentary sources to the database that underpins this work, particularly from local authority archives.

\section{Acknowledgements}

I would like to thank the five anonymous reviewers, whose constructive comments helped clarify certain aspects of this article, and Christopher J. Tribe for having translated it and also to Luís Gonçalves for drawing the maps. This research was conducted as part of the project UID/HIS/00057/2013 (POCI-01-0145-FEDER-007702) funded by national funds through the Foundation for Science and Technology and the European Regional Development Fund (FEDER) through the Competitiveness and Internationalization Operational Program (POCI) and PT2020, under the UID / HIS project / 00057 - POCI-010145-FEDER-007702. 